January 1992

\title{
Dynamic Insight into Psychoanalysis
}

Melinda Fudge, M.D.

Thomas Jefferson University

Follow this and additional works at: https://jdc.jefferson.edu/jeffjpsychiatry

Part of the Psychiatry Commons

Let us know how access to this document benefits you

\section{Recommended Citation}

Fudge, M.D., Melinda (1992) "Dynamic Insight into Psychoanalysis," Jefferson Journal of Psychiatry. Vol. 10 : Iss. 1 , Article 10.

DOI: https://doi.org/10.29046/JJP.010.1.009

Available at: https://jdc.jefferson.edu/jeffjpsychiatry/vol10/iss1/10

This Article is brought to you for free and open access by the Jefferson Digital Commons. The Jefferson Digital Commons is a service of Thomas Jefferson University's Center for Teaching and Learning (CTL). The Commons is a showcase for Jefferson books and journals, peer-reviewed scholarly publications, unique historical collections from the University archives, and teaching tools. The Jefferson Digital Commons allows researchers and interested readers anywhere in the world to learn about and keep up to date with Jefferson scholarship. This article has been accepted for inclusion in Jefferson Journal of Psychiatry by an authorized administrator of the Jefferson Digital Commons. For more information, please contact: JeffersonDigitalCommons@jefferson.edu. 


\title{
Book Reviews
}

\section{Dynamic Insight into Psychoanalysis}

\author{
THE USE OF THE SELF: COUNTERTRANSFERENCE AND COMMUNICATION IN \\ THE ANALYTIC SITUATION \\ Theodore J. Jacobs, M.D. \\ International Universities Press, Inc., 1991 \\ $\$ 40.00$ \\ 237 pages
}

Melinda Fudge, M.D.

I am not a psychoanalyst ... yet. As a second year resident, though, I am at a point in my career where I appreciate opportunities to peer into the world of psychoanalysis. It is to this end that I recommend reading The Use of the Self: Countertransference and Communication in the Analytic Situation by Theodore J. Jacobs, M.D. The book intends to demonstrate how an awareness of the nonverbal aspect of communication can lead to a greater understanding of the analytic process.

In presenting an overview of the theme, it is difficult to avoid using some of the psychoanalytic terminology used by the author. Through the use of case vignettes and an enjoyable and concise dialogue, one gains an appreciation of the ways in which the phenomenon of countertransference manifests itself in both subtle and overt ways. Many of the psychoanalytic concepts, however, are beyond the beginner level, thus making it less accessible to those who are unfamiliar with the more esoteric ideas in psychoanalysis.

In Sections I and II, entitled "Beginning an Analysis: Transference-Countertransference Interactions" and "Transference as a Process: Interactive Elements," Dr. Jacobs lays the groundwork for the development of higher level concepts that are used in the latter part of the book. He discusses the importance of awareness of transference, both positive and negative, and initial impressions in the opening phase of treatment. He presents the observation that secrets can develop between analyst and patient which lead to negative transference, strengthen resistance and influence the quality of the therapeutic alliance. The concept of transference neurosis is presented in such a way that one can appreciate its complexity as well as the ways in which it is played out between the analyst and the patient. His clinical stories lend themselves as examples of how both the analyst and the patient can unconsciously form unspoken secrets that recreate conflicts from the patient's past.

Section III entitled "Uses of the Analytic Instrument," reviews techniques 
whereby the analyst can enhance his/her ability to identify countertransference thus strengthening the therapeutic process. He points out how observation of our nonverbal behavior may be useful in picking up cues and may assist in the process of interpretation. The concept of complementarization is brought forth when considering the analyst's experience of conflictual bodily experiences during the sessions. Complementarization is defined as behavior expressive of a drive that tends to elicit in the object the complementary drive. Examples are given of how our awareness of posture and movement during the sessions can be valuable, nonverbal information within ourselves that is very likely a mirror-image of a drive that the patient is experiencing.

The final section, "Countertransference, Insight, and Self-Analysis," contains a fascinating discourse on countertransference. It calls attention to the subtler forms of countertransference that may, in the process of being overlooked or rationalized by the analyst, have great impact on the analytic process. The history of analytic thought about countertransference and resistance is briefly reviewed and different aspects of countertransference are defined and related to their respective schools of analytic thinking. Dr. Jacobs very effectively illustrates how the analyst can unconsciously use his/her countertransference reaction to screen from awareness the existance of certain resistances within the analyst. Examples are given of how he uses self-analysis to increase his awareness of those "smoke screens" and he gives a strong argument for making self-analysis a daily routine versus using it intermittently when the need is perceived. The observation is made that layers of countertransference reactions may exist within the analytic interaction with the purpose of one level serving to protect against the recognition of others.

Overall, Dr. Jacobs is able to take the reader on a journey that explores the inner dynamics of both the patient and the analyst and allows us to observe their reflection in the phenomenon of countertransference. The author does not confine himself to the issue of countertransference but rather provides a useful review of basic psychoanalytic concepts while highlighting major controversies and innovative thinking in the field of psychoanalysis today. 